\title{
EFFECT OF EXCULPATORY CLAUSE IN LESSEES' SURRENDER COVENANT
}

\begin{abstract}
Acovenant to surrender demised premises in as good condition as when received, "loss by fire and ordinary wear and decay excepted," raises the question as to whether the unqualified exculpatory phrase includes negligently caused fires. Illustrative is United States Fire Ins. Co. v. Phil-Mar Corp., ${ }^{2}$ a recent Ohio case, in which a lease of buildings contained such a stipulation, plus a provision that the lessee would pay to the lessor, in addition to rent, any increase in the cost of insurance premiums which might be occasioned by the special hazards of the lessee's occupancy, ${ }^{3}$ such increase to be limited to premiums for coverage not exceeding a stated amount. The lessor maintained the insurance and, after a fire, received payment from the insurance company, which, as subrogee of the lessor's right of action, sought to recoup its loss from the lessee. Although the lessee's negligence was conceded, the Ohio Supreme Court affirmed a directed verdict against plaintiff insurance company, holding that the exculpatory phrase had effectively extinguished both the lessor's right of action and that of its subrogee.

This case points up with graphic clarity the inconclusiveness of a strictly semantic approach to the interpretive problem involved. By shifting emphasis, the terminology can, with minimal ingenuity, be made to assume variant meanings. The majority, by dissection, construed "wear and decay" to be qualified by the adjective "ordinary," and since no like limitation was made regarding "fire," concluded that all types of fires must have been intended to be comprehended within the exception. The dissent, on the other hand, insisted that the phrase must be read as a unit, with a logical consistency between the two parts, and since negligence is excluded by implication from one portion, it must likewise be excluded from the other. ${ }^{4}$ While it is conceded that ex-

\footnotetext{
${ }^{2}$ Variations of this fairly standard wording are numerous but with slight effect, so long as "fire" is a named exception. Where the exception is for damages caused by the "elements," this is generally considered not to include fires caused by any human agency. 32 AM. JUR., Landlord \& Tenant § 8II (1941).

${ }^{3}$ Growing recognition is being attached to the significance of such a provision. See note 12 , infra.

"The argument is occasionally made that, historically, the tenant is not liable for damage to the premises due to accidentally caused fires. 5 I C.J.S., Landlord \& Tenant
}

266 Ohio St. 85,139 N.E.2d 330 (1956).
\end{abstract}


culpation between private contracting parties violates no vital policy factors, ${ }^{6}$ the underlying theory of the dissent in the instant case appears, nevertheless, to be founded upon historic abhorrence of attempts to limit liability for negligent acts and would, accordingly, require strict construction of such provisions.

Where exculpatory language is clear and unequivocal, there is no room for construction, and the instrument itself should be solely determinative; but where, as in the PhilMar case, the contract is ambiguous, it would seem that resort must be had to circumstances surrounding the transaction and to the commercial background of the contract in order to determine the true intent of the parties. In cases, for example, where the premises are not insured against loss by fire, ${ }^{\circ}$ the landlord must, of necessity, look only to the common-law liability of the tenant for recovery of his loss, and in the absence of incontrovertible language to the contrary, it is highly unlikely that the landlord would be said to have intended by the exceptions in the surrender covenant, to foreswear this avenue of recovery. On the other hand, this inference is not so clear in cases where the premises are insured. In as much as the normal fire insurance policy contains subrogation provisions, ${ }^{7}$

§ 408 (1947); I TIFEANY, LANDLoRd \& TENANT §§ III, II8 (1940); 32 AM. JUR. Landlord $\mathcal{E}^{\circ}$ Tenant $\S 802$ (1941). Thus, in order to give the exceptions in the surrender covenant some legal effect, the phrase "loss by fire excepted" must necessarily be allowed to include negligently caused fires, Cerny-Pickas \& Co. v. C. R. Jahn Co., 7 IIl.2d 393, 131 N.E.2d 100 (1955). An answer to this suggestion has been given by pointing out that such a provision does have a legal effect in that it relieves the tenant's obligation to rebuild when the buildings are destroyed by fire, leaving only liability in money damages. General Mills v. Goldman, I84 F.2d 359 (1950); CernyPickas \& Co. v. C. R. Jahn Co., supra; United States Fire Ins. Co. v. Phil-Mar Corp., supra. In Carstens v. Western Pipe \& Steel Co., 142 Wash. 259,252 Pac. 939 (1927), the interesting idea is suggested that this type of clause in leases came into vogue in England when there was uncertainty as to whether the lessee would be liable even for accidental fires, and thus does have an intended legal effect, without exculpation from liability for negligence even though the necessity for the clause has ended.

${ }^{5}$ General Mills v. Goldman, 184 F.2d 359 (1950); Cerny-Pickas \& Co, v. C. R. Jahn Co. 7 Ill.2d 393, 131 N.E.2d roo (1955); Kansas City Stockyards Co. v. A. Reich \& Sons, 250 S.W.zd 692 (Mo. 1952); Mansfield Mut. Ins. Co. v. Cleveland, C., C. \& St. L. R. Co., 74 Ohio St. 30, 77 N.E. 269 (1906). But cf. SWEANY, Validity of Contracts Against Consequences of Negligence, in Proceedings of the SECTION ON INSURANCE LAW OF THE AMERICAN BAR Association i55 (1948), concerning statutory prohibition of the lessor's exculpation.

'Brophy v. Fairmont Creamery Co., 98 Neb. 307, 152 N.W. 557 (1915); Carstens v. Western Pipe \& Steel Co., 142 Wash. 259, 252 Pac. 939 (1927).

7 "Subrogation. This company may require from the insured an assignment of all right of recovery against any party for loss to the extent that payment therefor is made by this company." 1943 New York Standard Fire Policy. 
the release by the insured of a possible tortfeasor without consent of the insurer might well jeopardize the right of the insured to recover on the policy, ${ }^{8}$ or render the insured liable in damages to the insurer to the extent of the insurer's consequent loss. ${ }^{9}$ Accordingly, if a like result were ascribed to the release of a potential tortfeasor prior to any loss, it could reasonably be inferred that the lessor did not intend to exculpate the tenant at the expense of forfeiting his right to recovery on the policy. Nevertheless, a well recognized judicial reluctance to allow technical language to work a forfeiture of insurance ${ }^{10}$ makes such a result unlikely in the absence of a clear policy provision to that effect; and since fire insurance policies are generally standardized as to form, ${ }^{11}$ such a provision would, indeed, be rare. Thus, it appears that while examination of the legal effects of equivocal exculpatory clauses may afford some indicia of the intent of the parties, where insurance is involved, without other supportive elements, this alone will be inconclusive.

More apposite criteria are found in cases where the courts have recognized the economic reality that, irrespective of special provision, the tenant actually pays, as additional rent, the premium cost and should, therefore, be entitled to the benefit of the insurance. ${ }^{12}$ Should it be

\footnotetext{
Vance, Insurance § 134 (c) (3rd ed. I95I); United States Fire Insurance Co. v. Phil-Mar Corp., 166 Ohio St. 85, 139 N.E.2d 330 (1956). In reference to the standard fire policy, the Supreme Court of North Carolina stated: "They [the words of the subrogation clause] are inserted in the policy, not by the company or by the plaintiff, but by the statute. To fail to give them force and effect is to nullify the statute." Buckner v. United States Fire Ins. Co., 209 N.C. 640, I84 S.E. 520 (1936).

- Some courts allow the insurer to be reimbnrsed out of the amount received, less costs of recovery to the insured, up to the full amount paid by the insurer; others limit reimbursement to that amount by which the money received from the wrongdoer, together with the insurance, exceeds the loss and cost of recovery incurred by the insured. 29 AM. JUR., Insurance § 1346; VANCE, INSURANCE § 134 (3rd ed. 1951); 2 Richards, INSURANCE $\$ \S 198,563$ (5th ed. 1952).

${ }^{10}$ In Ensell v. Lumber Ins. Co., 88 Ohio St. 269, 102 N.E. 955 (1913), the policy contained a stipulation for subrogation and the insured had, by contract prior to the loss, specifically released the tortfeasor from liability. The court held that such a stipulation in the policy could only work a forfeiture strictissimi juris; that stipulation being inserted in the policy by the insurer for his own protection would be construed most strongly against him and in favor of the insured. See 29 AM. JUR., Insurance $\S 166$.

${ }^{11}$ Forty-four states plus Alaska, Hawaii, and the District of Columbia have adopted the 1943 New York Standard Fire Policy either by ruling of the insurance commissioner or other supervising official, or by legislative enactment. Of the remaining states, three still use the 1945 Massachusetts Standard Form, and Texas uses its own distinctive policy. 3 RiChardS, INSURANCE $\$ 497$ ( 5 th ed. 1952).

${ }^{12}$ Referring to the provision requiring the lessee to pay the extra insurance premiums occasioned by its occupancy, the court said: "Clearly under this section of th" lease
} 
denied him, he would be forced, in order to protect himself, to insure the premises a second time-at best, an uneconomical procedure..$^{18}$ Furthermore, although the idea is strongly opposed by insurance companies, subrogation may more accurately be considered a windfall to the insurer than an inherent right. ${ }^{14}$ For although it is true that at common law subrogation is allowed an insurer after payment of the loss, even without a stipulation to that effect in the policy, ${ }^{15}$ the fact remains that the insurer is paid to assume the risk of loss, and its premium rates are established accordingly. ${ }^{16}$ The standard fire insurance policy covers fires caused by negligence as well as those caused by accident or natural causes, ${ }^{17}$ and premium rates are calculated on the frequency of occurrence of all three types, without regard to subrogation rights. ${ }^{18}$ ACcordingly, there is a perceptibly growing leniency displayed toward the negligent lessee. That this trend is not unopposed, however, is indicated by numerous dissents; ${ }^{19}$ and at least one state has insisted that an

it was contemplated that the lessor. would carry insurance on the property and look to the insurance for compensation for any loss by fire." United States Fire Ins. Co. v. Phil-Mar. Corp., 166 Ohio St. 85, 139 N.E.2d 330, 333 (1956).

${ }^{18}$ In Cerny-Pickas \& Co. v. C. R. Jahn Co., 7 Ill.2d 393, 398, 131 N.E.2d 100, 103 (1955) the court says: "Under the construction urged by the lessor it would be necessary for both parties to the lease to carry fire insurance if they are to be protected. The lessee would have to insure against fires due to his negligence, and the lessor against fires due to other causes. Whether the kind of policy the lessee would have needed was commercially available when the present lease was entered into is at least dubious." Citing 3 I Boston L. REv. 47 (1951), which indicates that such a policy might now be available.

${ }^{14}$ Suggested forcefully in 2 Richards, INSURANCE $§ 183$ (5th ed. 1952).

${ }^{25} 29$ AM. JUR., Insurance § 1335 ; VANCE, INSURANCE § 134 (3rd ed, 1951 ).

${ }^{28}$ "The insurance rate on a building, according to insurance authorities, is a reasonably accurate reflection of the loss probabilities of that particular class of property." Nolting, How Municipal Fire Defenses Affect Insurance Rates 50 (1939); "The two systems in most common use for schedule rating are the Universal Mercantile Schedule and the Analytic Schedule. A third system, which undertakes to incorporate the element of experience, is known as the Experience Grading and Rating Schedule. This last system has never been actually adopted for use and is, therefore, of little. practical concern." Magee, General Insurance (4th ed. 1954). See also, PatTERSON, ESSENTIALS OF INSURANCE LAW 122 (1935).

${ }^{17}$ Goldin, Principles of NeW York Standard Fire Insurance Policy 76 (1938).

${ }^{18}$ See note 16 supra. But there are indications that interest of fire insurance companies in potential subrogation claims is increasing. See LowRY, Recoveries in Fire Losses, in Proceedings of the Section on InsUrance LaW of THE AMERICaN Bar Association 199 (1949).

${ }^{19}$ General Mills v. Goldman, 184 F.2d 359 (8th Cir. 1950); Cerny.Pickas \& Co. v. C. R. Jahn Co. 7 Ill.2d 393, 131 N.E.2d 100 (1955); United States Fire Ins. Co. v. Phil-Mar Corp., 166 Ohio St. 85,139 N.E.2d 330 (1956). 
intention on the part of the landlord to relieve a tenant from liability for negligent damage to insured premises can never be inferred from equivocal language. ${ }^{20}$

In the final analysis, it becomes clear that the contemporary trend evinces an approach more in keeping with the probable intent of the parties and the economic realities of the situation than did earlier cases. Nevertheless, as long as some courts adhere to a purely semantic construction of exculpatory provisions, it will be necessary for lessors and lessees to adopt self-help measures. The most obvious of these is, of course, a specific exception of negligently caused fire damage in the surrender covenant. ${ }^{21}$ A more practical device, however, would be that of including both landlord and tenant as named insureds "as their interests may appear."22 With subrogation against the tenant thus obviated, a cover-all exception in the surrender covenant would not be objectionable to the insurer, and by this means, the tenant could block recovery by the landlord for fire losses in excess of the insurance coverage.

This latter suggestion presupposes either willing cooperation between landlord and tenant, or at least an equality of bargaining power. Where, however, the relationship between the parties is not on such a plane, essentially the same result may be had if the lessee covenants to insure the property for the lessor's benefit and secures an agreed amount and type of coverage in his own name..$^{23}$ If the lessor is able to dictate terms under which the lessee assumes full responsibility for

${ }^{20}$ "Contracts for exemption from liability for negligence are not favored by the law, and are strictly construed against the party asserting it. The contract will never be so interpreted in the absence of clear and specific words that such was the intent of the parties." Winkler v. Appalachian Amusement Co., 238 N. C. $589,596,79$ S.E.2d 185,190 (1953).

${ }^{21}$ A normal inspection of the risk would doubtless include an examination of the terms of the lease, and such a provision would be likely to cause objection by the insurer. Further, insertion of such a clause in a lease drawn after the issuance of the policy would be derogatory to the rights of the insured. The analogy of the insurer to a surety is drawn in 6 VAND. L. REv. 408 (1953), noting Kansas City Stockyards Co. v. A. Reich \& Sons, 250 S.W.2d 692 (Mo. 1952). See also Remarks of John M. Breen, Insurance Series, No. 97, American Management Association (I952).

${ }^{22}$ It is well settled that both have an insurable interest. Goldin, Principles of the New York Standard Fire Insurance Policy 26 (1938); Vance, Insurance $\S 29$ (3rd. ed. 195 I); I Richards, INSURANCE $\$ 78$ (5th ed. 1952).

${ }_{23}$ "And a tenant who has agreed verbally to keep the demised property insured is liable to the lessor for a breach of that agreement, and has an insurable interest in the property to the extent of the amonint agreed to be insured." Berry v. American Cent. Ins. Co., 132 N.Y. 49, 56, 3 Q N.E. 254, 255 (1892). 
the property, protection may be had for the lessee through a fullcoverage type of liability insurance against loss or damage. ${ }^{24}$

It would appear that under either of the arrangements described, the total cost of the insurance to the lessor and lessee would be about the same as it would be to a lessor who maintained the policy alone; but, in addition, the protection to both parties would be more effective, and the likelihood of litigation in the event of loss reduced.

"Sinnott, Insurance Covering Contractually Assumed Liability, Insurance Series, No. 97, AMERICAN MANaGEMENT Association. 